\section{An Analysis of Graduate Theses on Early Childhood Education: The Case of Turkey}

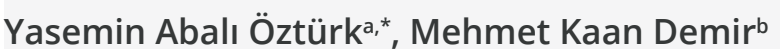

\begin{tabular}{ll}
\hline Received: & 16 March 2018 \\
Revised: $\quad 28$ May 2018 \\
Accepted: $\quad 08$ June 2018 \\
ISSN: 1307-9298 \\
Copyright @ IEJEE \\
www.iejee.com
\end{tabular}

DOI: 10.26822/iejee.2018541307

\begin{abstract}
The primary concern of this study is to reveal the general tendencies (genders of the authors/supervisors, change in the number of graduate theses by year, number of research problems-results-suggestions, focal points, the corpus by research models/methods, data collection methods/tools, and population/sample group) of graduate on early childhood education in Turkey between 2005 and 2017 . The sampling of the present research study consists of 182 graduate theses. The study relies on the retrieval of the desired data by document analysis through a systematic examination of the available theses by using a thesis examination form developed by the researchers. The results revealed that $85 \%$ of the authors were female and almost half of the supervisors were assistant professors and moreover 59\% of the supervisors were female. The study also showed that a great majority of the examined theses contained 0-10 research problems, results and suggestions. It was also figured out in the study that the focal point of the thesesis majorly qualifications of preschool teachers, characteristics and tendencies of parents, effects of different approaches/methods on early childhood education, characteristics of children in early childhood education or at preschool age. It was observed that $68.1 \%$ of graduate theses were quantitative studies and that the least employed research method was observation $(0.5 \%)$, case study $(1.1 \%)$, interview $(1.6 \%)$ and phenomenological method $(1.6 \%)$, while the most frequently administered data collection tool, accounting for $65 \%$, was questionnaire.
\end{abstract}

Keywords: Early childhood education, graduate education, thesis analysis, Turkey

\section{Introduction}

Early childhood constitutes the most critical part of life in terms of adopting values that children will need socially. Because children in this period go through the fastest stage of their development, where their personality is built and they are strongly affected by their immediate environments and open to any kind of learning (Günindi, 2015). Early childhood education as the first stage of formal education is the first floor of a building, which should be constructed on a firm basis to achieve an egalitarian and high-quality education (AÇEV-ERG, 2013, p. 5). Many projects have been produced and carried out and plans, goals, policies, and principles have been created to improve the national education system in Turkey so far; however, the desired results have not been achieved. In consideration of the decisions of the National Education Councils and educational goals and policies in the five-year development plans having been implemented since 1963 , it can be realized that what is said and what is done fail to overlap (Ĕgitim-Bir-Sen, 2010, p. 11).

United Nations Children's Fund (UNICEF) and United Nations Development Programme (UNDP) are the two organizations striving for the global dissemination of early childhood education. It can be observed in the case of Turkey that early childhood education institutions are administered by various offices and authorities. Early Childhood Education (EÇE) in Turkey is orchestrated by the three general directorates of the Ministry of National Education. Privately owned pre-kindergartens (3-6) and kindergartens (5-6) report to the Directorate of Early Childhood Education, application pre-kindergartens and kindergartens (3-6 Year-Olds and Project of Mother-Father-Child Education) to the Directorate of Girls' Technical Education, the Program of Mother-Child Education (AÇEP) and the Program of Mother-Child Education for 0-4 year-olds to the Directorate of Apprenticeship and Non-for- mal Education. Children's homes (0-12), nurseries, and day cares $(0-6)$ operate as regulated by the Social Services and Child Protection Agency (Eğitim-Bir-Sen, 2010, p. 19).

A high-quality and compulsory early childhood education is regarded as a prerequisite to a sustainable national development and a sustainable competitive capacity in the international setting. Contemporary administrators and decision-makers should act to make educational investments to secure the future of Turkey and to solve education-related problems in a systematic way starting with early childhood education and elementary school. This is not an option but a necessity (Özdemir, Bacanlı \& Sözer, 2007). Implementations by educational policies concerning this necessity are only possible when and if the decisions and prospective plans are based on scientific research studies. Research on early childhood education plays a crucial role in the description of the existing condition and in the future plans. Over the last years, the number of academic studies has increased in Turkey, the benefits of early childhood education have come to be discussed by policy makers and the goals have been set to improve early childhood education (Kaytaz, 2005). Among these research studies are graduate theses written at the institutes of universities as per the Law on Higher Education (Law no: 2547) effective as of 1981.

In the Turkish education system, different approaches and theories have been adopted at different periods to produce teaching programs, and these approaches and theories have been taken into account when setting educational goals (Arı, Kızılaslan Tuncer \& Demir, 2016). Turkey is a country ardently working to make early childhood education compulsory. Turkey has come to understand the value of early childhood education, which was realized by other countries many years ago. The rising importance of this field has entailed an indepth analysis of relevant studies. Not many studies were 
Table 1. Graduate Theses in the Corpus by Year

\begin{tabular}{lrrrrrrrrrrrrr}
\hline & 2006 & 2007 & 2008 & 2009 & 2010 & 2011 & 2012 & 2013 & 2014 & 2015 & 2016 & Total \\
\hline Frequency & 11 & 10 & 13 & 15 & 19 & 19 & 22 & 23 & 19 & 21 & 10 & 182 \\
\hline Percentage & 6.0 & 5.5 & 7.1 & 8.2 & 10.4 & 10.4 & 12.1 & 12.6 & 10.4 & 11.5 & 5.5 & 100 \\
\hline $\begin{array}{l}\text { Cumulative } \\
\text { Percentage }\end{array}$ & 6.0 & 11.5 & 18.7 & 26.9 & 37.4 & 47.8 & 59.9 & 72.5 & 83.0 & 94.5 & 100 & \\
\hline
\end{tabular}

identified in the literature examining master's theses and doctoral dissertations on early childhood education. Among the conducted studies are an evaluation of the scientific studies into medical and educational domain of early childhood development in Turkey between 2000 and 2007 (Bertan et al., 2009), an analysis of the theses on early childhood education (Altun, Şendil \& Şahin, 2011), theses on drama in early childhood education (Can Yaşar \& Aral, 2011), theses on games in early childhood education (Kaytez \& Durualp, 2014), theses on early childhood education between 2000 and 2014 (Durukan, Atalay \& Şen, 2015), theses on inclusion in early childhood education (Taştepe et al., 2016), theses on early childhood education between 2002 and 2011 (Ahi \& KIldan, 2013). This shows that more research should be carried out by considering scopes, purposes, and research domains.

\section{Aim}

The primary concern of this study is to reveal the general tendencies of graduate theses on early childhood education between 2005 and 2017. Because 2005 was the year a radical change was made in Turkish education system and declared to be a revolutionary year. Ever since 2005, the constructivist approach based on progressive educational philosophy has underlain educational programs in the Turkish education system (Erdoğan, 2007). 2005 was marked as the starting point of the present research.The following research questions were produced for the purpose of the study:

1. What is the distribution of the open-access graduate theses between 2005 and 2017 by level and year?

2. What is the distribution of the graduate theses in the corpus by the gender/title of their authors/ supervisors, the number of research problems, the number of results and suggestions?

3. What is the distribution of the graduate theses in the corpus by research focus?

4. What is the distribution of the graduate theses in the corpus by research models/methods, data collection methods/tools, and population/sample group?

\section{Method}

Since this study describes the distribution of graduate theses on early childhood education by their sub-goals, it is a descriptive survey employed to describe structures and operations of objects, institutions, and societies as they are (Cohen, Manion \& Morrison, 2007).

\section{Population and Sampling}

The population of the study, as of June 2017, consists of 520 open-access graduate theses written on Early Childhood Education in Turkey between 2005 and 2017, which are archived in the database of the National Thesis Center of Publication and Documentation Department of the
Council of Higher Education. 182 graduate theses were isolated from these 520 theses by stratified sampling to create the corpus for in-depth analyses. Stratified sampling is used in the presence of sub-strata/-groups in a population with preset limitations (Yıldırım \& Şimşek, 2005). To reinforce the representativeness of the sampling, the authors resolved to assign 35\% of the population as the present study's corpus. $35 \%$ of the graduate theses per each year was calculated by stratified sampling and 182 (35\%) of the 520 theses were assigned as the corpus. The theses in the sampling were carried out at 46 different universities.

As indicated in Table 1, 23 (12\%) of the graduate theses were written in 2013. This means that 2013 marks the year when the highest number of theses was carried out in consideration of the corpus. Moreover, it can be concluded from the analysis of the theses that the lowest number of theses was produced in 2007 and 2016.

\section{Data Collection and Analysis}

Document analysis was used as the data collection method relying on the systematic examination of documents to harvest data (Karadağ, 2009). Thesis style guides of universities, sets of information in graduate theses, characteristics of scientific research studies and similar studies were reviewed to produce a thesis analysis form for the systematic analysis of the theses in the corpus. To ensure validity, the form was delivered to experts (3 experts from the field of educational sciences, one expert from the field of early childhood education) and revised based on their feedback. The researchers performed the analyses relying on the thesis analysis form.

The data (supervisors' gender and title, research model, etc.) which were suitable for statistical analysis were analyzed with SPSS (a statistical software program) for descriptive statistics (frequency and percentage). The remaining data were analyzed by content analysis.

\section{Findings}

\section{Findings on the First Sub-goal}

In view of the first research question "What is the distribution of the open-access graduate theses between 2005 and 2017 by level and year?", the levels (master's or doctoral) of the open-access graduate theses archived by the Publication and Documentation Department of the Council of Higher Education are presented in Figure 1.

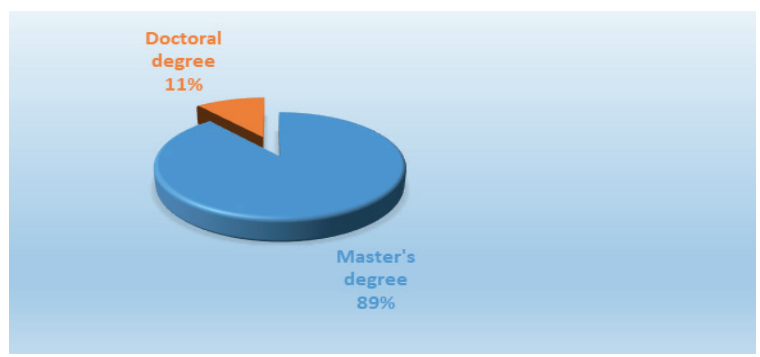

Figure 1. Distribution of the graduate thesis between 2005 and 2017 by level 
It can be understood from Figure 1 that doctoral dissertations and master's theses account for $11 \%$ (57) and $89 \%$ (463) of the 520 open-access graduate theses, respectively, archived by the Publication and Documentation Department of the Council of Higher Education. The reason why master's theses on early childhood education are almost eight times more than doctoral dissertations can be claimed to be the higher number of master's programs in the field than that of the doctoral programs. It can also be considered that the subject matter at stake has not been adequately studied in the doctoral dissertations.

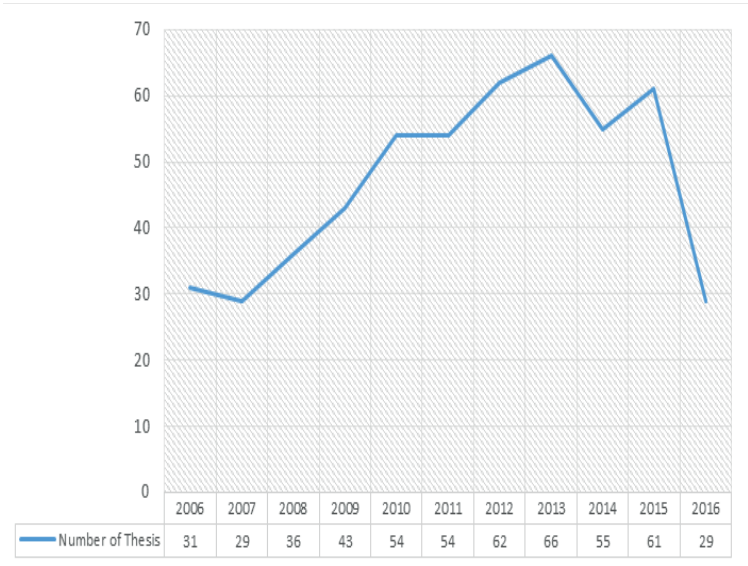

Figure 2. Change in the number of graduate theses by year

Figure 2 provides the by-year distribution of the 520 open-access graduate theses between 2005 and 2017, archived by the Publication and Documentation Department of the Council of Higher Education. The fall in 2016 may be misleading because access to the majority of the theses written in 2016 were prohibited by the authors and the number appears to be lower due to the fact that the data collection was conducted by June 2017. The analysis of the fluctuations before 2016 yielded a decline by $6 \%$ between 2006 and 2007 and by 17\% between 2013 and 2014. Except for these cases, the number of theses was observed to increase with every passing year.

\section{Findings on the Second Sub-goal}

Figure 3 shows the gender-based distribution of the authors/supervisors of the 182 open-access theses archived by the Publication and Documentation Department of the Council of Higher Education in consideration of the research question "What is the distribution of the graduate theses in the corpus by the gender/title of their authors/ supervisors, the number of research problems, the number of results and suggestions?"

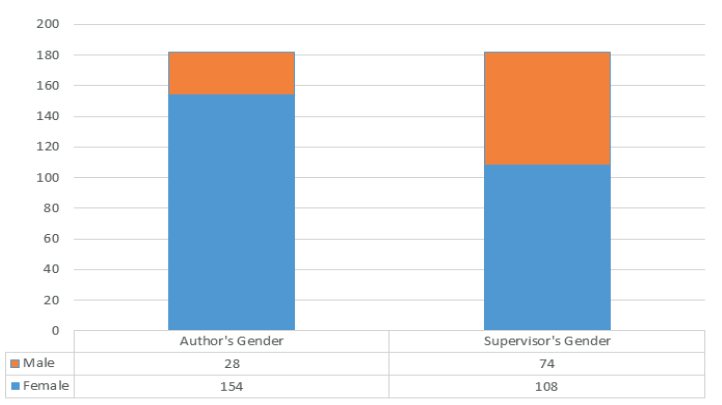

Figure 3. Distribution of graduate theses by genders of the authors/supervisors

As indicated in Figure 3, 154 (85\%) and 28 (15\%) of the researchers having carried out the theses on early childhood education were female and male, respectively. This may be resulting from the fact that early childhood education is considered to be more suitable for women. In fact, undergraduate programs of early childhood education at colleges of education are dominated by female students. It was revealed that $108(59 \%)$ and $74(41 \%)$ of the supervisors were female and male, respectively. The percentage of the female supervisors is not as high as that of the female authors. It can be inferred from this finding that male researchers at colleges of education are as interested in early childhood education as female scholars.

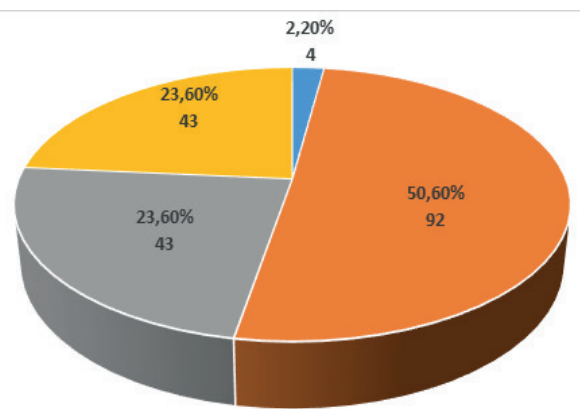

- Lecturer (PhD) = Assistant Professor = Associate Professor = Professor

Figure 4. Distribution of graduate theses by titles of the supervisors

Figure 4 on the distribution of the supervisors of the graduate theses in the corpus by their titles indicates that $23.6 \%$ of the supervisors are professors, $23.6 \%$ are associate professors, $50.6 \%$ are assistant professors and $2.2 \%$ are lecturers with a doctoral degree. This finding may evidence that majority of the faculty members studying early childhood education are assistant professors. According to the 2015-2016 statistics issued on the titles of faculty members by the Council of Higher Education, 22416 professors, 15023 associate professor and 35301 assistant professors are employed at universities in Turkey (https:// istatistik.yok.gov.tr). It can be concluded in view of these figures that the distributions concerning the titles of the supervisors of the examined theses exhibit a similar pattern of distribution to that of the faculty members at universities across Turkey.

The distribution of the graduate theses by the investigated research problems, the obtained results, and the offered suggestions is given in Figure 5 in the context of the second research problem.

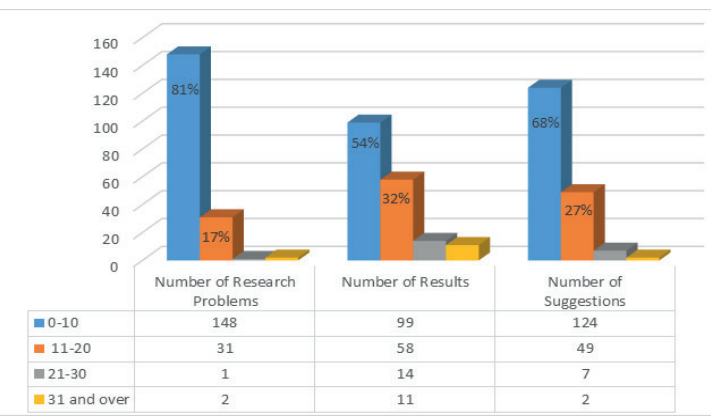

Figure 5. Distribution of the graduate theses by research problems, results and suggestions

Figure 5 manifests that $81 \%, 17 \%, 54 \%$ and $32 \%$ of the 182 graduate theses contain 0-10 research problems, 11-20 solutions to the research problems, 0-10 results, and 1120 results, respectively. Relatedly, while $68 \%$ contain $0-10$ suggestions, $11-20$ suggestions were identified in $27 \%$. 
Table 2. Graduate Theses in the Corpus by Focal Points

\begin{tabular}{|c|c|c|}
\hline Focal points & $\mathrm{f}$ & $\%$ \\
\hline 1. Qualifications of preschool teachers & 33 & 18.1 \\
\hline 2. Characteristics and educational backgrounds of parents & 27 & 14.8 \\
\hline 3. Effects of different approaches/methods on early childhood education & 27 & 14.8 \\
\hline 4. Characteristics of children in or at the age of early childhood education & 24 & 13.1 \\
\hline 5. Readiness for early childhood and elementary education & 16 & 8.8 \\
\hline 6. Qualifications of administrators & 13 & 7.1 \\
\hline $\begin{array}{l}\text { 7. Available education programs in Turkey and analysis of the decisions of the Ministry of National } \\
\text { Education }\end{array}$ & 10 & 5.5 \\
\hline 8. Analysis of TV programs, PC games and books & 10 & 5.5 \\
\hline 9. Education of students with special needs & 6 & 3.3 \\
\hline 10. Perception of gender/sexual harassment/child abuse & 5 & 2.7 \\
\hline 11. Characteristics of preschool teachers & 5 & 2.7 \\
\hline 12. Early childhood education abroad & 3 & 1.6 \\
\hline $\begin{array}{l}\text { 13. Others (communication, peace education, education of children at Social Services and Child Pro- } \\
\text { tection Agency and juvenile detention centers, in-class spaces for relevant topics, concept of accuracy, } \\
\text { etc.) }\end{array}$ & 11 & 6.0 \\
\hline
\end{tabular}

Note: More than one subject is investigated in some graduate theses/dissertations. Each researched topic was considered in the creation of this table.

Generally speaking, the numbers of research problems, results and suggestions were discovered to be densely represented in the range of $0-10$.

\section{Findings on the Third Sub-goal}

In response to the question "What is the distribution of the graduate theses in the corpus by their research focuses?", the researchers analyzed the contents of the graduate studies to identify the focal points of the 182 open-access graduate theses included in the corpus and archived by the Publication and Documentation Department of the Council of Higher Education. The researchers identified the foci of the graduate theses in the corpus and grouped them into 13 categories, i.e. qualifications of preschool teachers, characteristics and educational backgrounds of parents, effects of different approaches/methods on early childhood education, characteristics of children in or at the age of early childhood education, readiness for early childhood and elementary education, qualifications of administrators, available education programs in Turkey and analysis of the decisions of the Ministry of National Education, analysis of TV programs, PC games and books, education of students with special needs, early childhood education abroad, characteristics of preschool teachers, perception of gender/sexual harassment/child abuse and the like. These focal points are presented in Table 2.

Table 2 indicates that $18.1 \%$ (33) of the examined graduate theses are concentrated on the qualifications of preschool teachers. A detailed analysis of this category titled as "teacher qualifications" revealed that 7 of the 33 theses are concerned with professional satisfaction and burnout levels and 6 with teachers' empathetic tendencies and levels of their emotional intelligences. 8 (30\%) of 27 theses on characteristics and educational backgrounds of parents were observed to deal with mother-father support programs and parental participation projects. It was found out from the content analyses of 27 theses, mostly experimental, on the effects of different approaches/methods on early childhood education that 5 were focused on Montessori approach, 3 on drama management, and 3 on teaching with games.

The theses on the characteristics of children in or at the age of early childhood education account for $13 \%$ of the entire corpus. The content analyses showed that 9 (38\%) of the 24 theses investigated levels of social skills of students.

\section{Findings on the Fourth Sub-goal}

In the context of the fourth research question "What is the distribution of the graduate theses in the corpus by research models/methods, data collection methods/ tools, and population/sample group?", the findings on the scientific research types of the 182 open-access theses archived by the Publication and Documentation Department of the Council of Higher Education are presented in Figure 6 . There are many classifications concerning the types of scientific research. However, it has been explored by the analyses of the international data sources such as EBSCO, ERIC, etc. that methods of the submitted papers were mostly indicated as qualitative, quantitative, and mixed (Birol, 2013). For the purpose of the study, qualitative, quantitative, and mixed research types accepted by EBSCO and ERIC were taken into account to discuss the distribution of graduate theses/dissertations by the type of scientific research type.

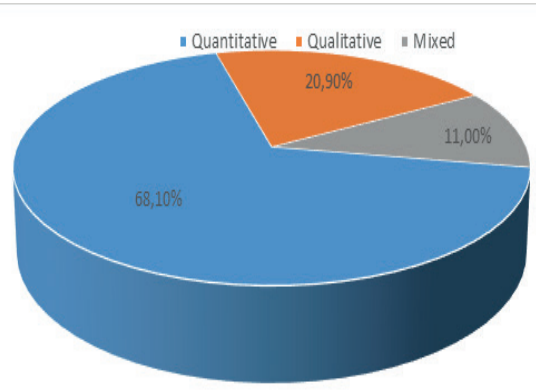

Figure 6.Distribution of graduate theses by scientific research types

It is obvious from Figure 6 that most (124) of the 182 graduate theses are quantitative, accounting for $68.1 \%$. The theses using mixed research method, which can be defined as a method incorporating qualitative and quanti- 
tative methods and approaches and data collection techniques associated with both in a single study or multiple studies (Creswell, 2006; Johnson \& Onwuegbuzie, 2004) account for $11 \%$ (20) of the examined studies.

The distributions of the graduate theses in the corpus by research method are provided in Figure 7. To identify the research methods, the methods labeled as "research method" by the authors were taken into account. These methods were not further investigated.

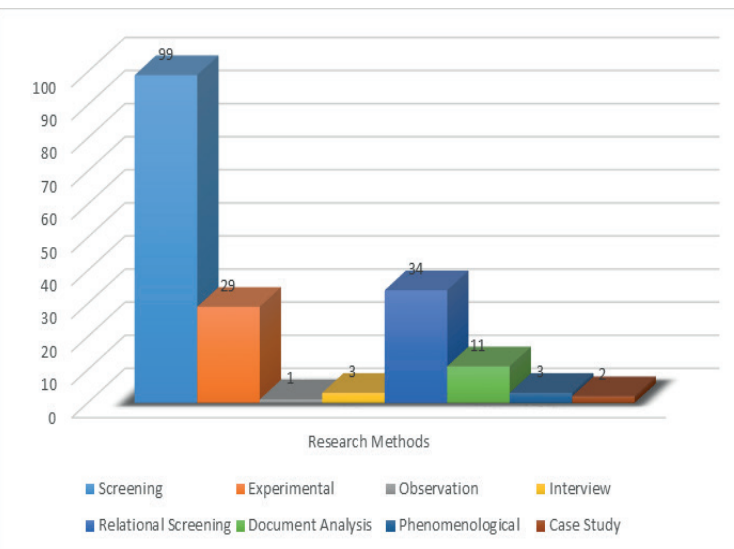

Figure 7.Distribution of graduate theses by scientific research methods

As observable in Figure 7, the authors of $54 \%$ (99) of 182 graduate theses used screening method, which can be defined as the description of a past or present phenomenon, individual and/or an object as it exists under its respective condition (Köse, 2013, p. 111). The least employed research methods were observation $(0.5 \%)$, case study (1.1\%), interview (1.6\%) and phenomenology (1.6\%).

The analysis of the 182 graduate theses in terms of data collection tools showed that 1 data collection tool was used in 122 (67\%) of the studies, 2 in $54(30 \%)$, and more than 2 in 6 (3\%). Relying on the related statements of the authors, the distribution of the used data collection tools are provided in Figure 8.

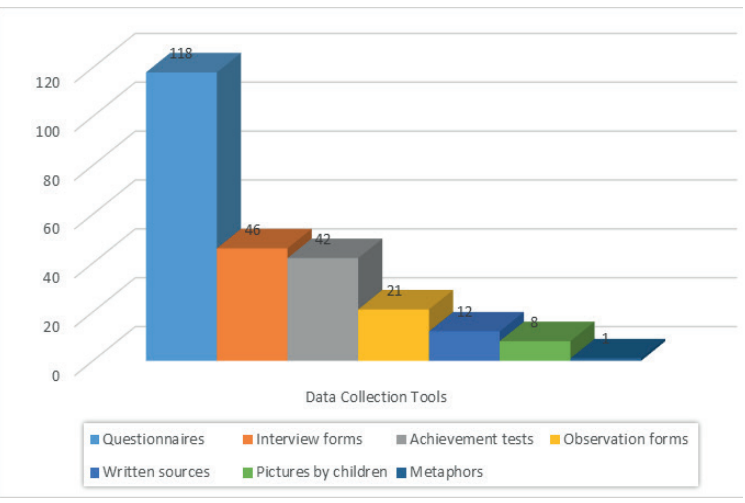

Figure 8. Distribution of graduate theses by data collection tools

Note: More than one data collection tool is employed in some graduate theses/dissertations. Each tool was considered in the creation of this table.

The data in Figure 8 evidence that the most frequently used data collection tool (65\%) in the graduate theses was questionnaire. The least frequent data collection tools are written sources (literature, preschool book) by $7 \%$, pictures by children when at preschool age by $4 \%$, and metaphors by $0.5 \%$.
Lastly, in consideration of the findings concerning the fourth research problem on the population and sampling in the corpus, it was found out that $118(65 \%)$ of the authors conducted their studies on a single sample, 54 (30\%) on two and $10(5 \%)$ on more than two samples. The distributions by sample groups in the graduate theses are shown in Figure 9.

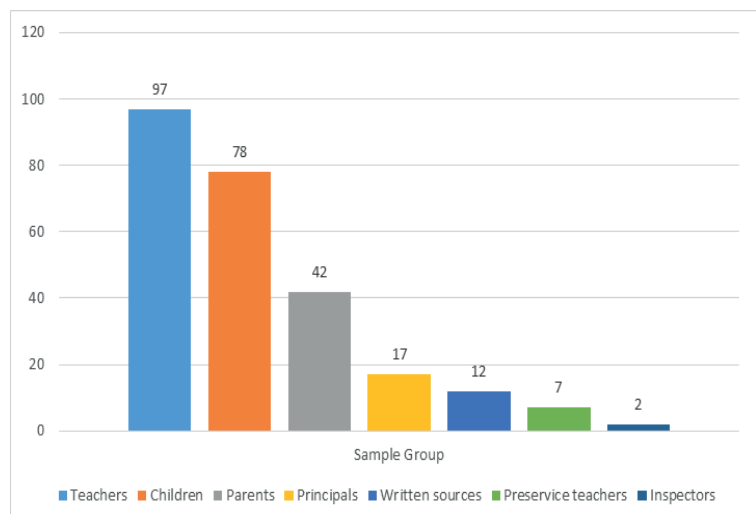

Figure 9. Distribution of the graduate theses by sample groups.

Note: More than one sample is included in some graduate theses/ dissertations. Each sample was considered in the creation of this table.

It can be realized from Figure 9 that 53\% (97), 43\% (78), and $23 \%$ (42) of the theses were conducted on preschool teachers, children at preschool age (children in or at the age of preschool), and parents, respectively.

\section{Conclusion, Discussion and Suggestions}

Over the last decade, substantial advancements have been achieved in early childhood education and this issue has happened to be included in educational policies of Turkey. In 2008, 100\% schoolarization of five-year-olds at preschools was announced among the goals of the Ministry of National Education (MEB). However, lowered school starting age proposed by the " $4+4+4$ " education system effective since the 2012-2013 academic year and failure to include early childhood education in compulsory education have caused us to lose the achievements related to early childhood education since 2008 (Oral, Yaşar \& Tüzün, 2016, p. 6).

Services offered for individuals at the age of 0-5 are not accessible by everybody in Turkey. 2015-2019 Strategic Plan of the Ministry of National Education includes strategies to disseminate early childhood education, diversify models of service offering to promote participation in early childhood education, support the access of households and regions with limited opportunities to early childhood education, and enforce the regulations to decrease the cost of early childhood education covered by families. In this very plan, schoolarization in terms of early childhood education has been listed among the priorities. Besides, the dissemination of early childhood education has been included in the Program of the 65th Government. In 2017 as well, notable announcements have been made on the necessity of a compulsory early childhood education. The 2017-2019 Medium-Term Program of the Ministry of Development too suggests that early childhood education should be gradually made compulsory by 2019 (TEDMEM, 2017, p. 4).

The importance of the education in the first five years of life and the relevant studies has been seemingly increasing in modern societies. The primary concern of this study 
is to reveal the general tendencies of graduate on early childhood education in Turkey between 2005 and 2017. The obtained results concerning the four research problems were compared with the results of the research in the literature and suggestions were made accordingly.

In reply to "What is the distribution of the open-access graduate theses between 2005 and 2017 by level and year?", it was found out that $11 \%$ of the 520 graduate theses written between 2005 and 2017 were doctoral dissertations, whereas $89 \%$ were master's theses. Kaytez and Durualp (2014) concluded in the study they conducted on 38 theses in 2014 that the number of doctoral dissertations was exiguous. Ahi and Kıldan (2013) carried a research study on 77 theses in 2013 to find out that there were only 5 doctoral dissertations due to the low number of doctoral programs as they claimed. Taştepe et al. (2016) expressed in their analysis of graduate theses that the number of master's theses were higher than doctoral dissertations. Bertan et al. (2009) reported that master's theses, graduation assignments, medical specialization theses, and doctoral dissertations accounted for $62 \%$, $14 \%, 12 \%$, and $11 \%$ of the analyzed studies, respectively, in the study into theses and other scientific studies on early childhood development. Can Yaşar and Aral (2011) reported that $82.5 \%$ of the graduate theses as the corpus of their study constituted master's theses, while doctoral dissertations account for $17.5 \%$. The results concerning the distribution of graduate theses/dissertations by level in the present study substantiate those of the respective research.

The investigation into "What is the distribution of the graduate theses in the corpus by the gender/title of their authors/supervisors, the number of research problems, the number of results and suggestions?"indicated that $85 \%$ and $15 \%$ of the authors of the studied theses were female and male, respectively, whereas female and male supervisors were found out to account for $59 \%$ and $41 \%$, respectively. The rates concerning the titles of the supervisors were discovered to be $\% 23.6$ for professors, $23.6 \%$ for associate professors, $50.6 \%$ for assistant professors and $2.2 \%$ for lecturers with a doctoral degree. Moreover $81 \%$ and $17 \%$ of the analyzed graduate theses were found to have attempted to solve 0-10 and 11-20 research problems, respectively, while $54 \%$ and $32 \%$ were observed to have produced $0-10$ and $11-20$ solutions, respectively. Accordingly, $68 \%$ of the graduate studies at stake were figured out to contain 0-10 suggestions while 11-20 suggestions were identified in $27 \%$. Durukan, Atalay and Şen (2015) noted that $86 \%$ and $14 \%$ of the authors of the theses in their study were female and male, respectively. The analysis of the supervisors showed that $56 \%$ of the supervisors were assistant professors.

In reply to the research problem"What is the distribution of the graduate theses in the corpus by their research focuses?", the researchers identified the foci of the graduate theses in the corpus as qualifications of preschool teachers, characteristics and educational backgrounds of parents, effects of different approaches/methods on early childhood education, characteristics of children in or at the age of early childhood education, readiness for early childhood and elementary education, qualifications of administrators, available education programs in Turkey and analysis of the decisions of the Ministry of National Education, analysis of TV programs, PC games and books, education of students with special needs, early childhood education abroad, characteristics of preschool teachers, perception of gender/sexual harassment/child abuse and the like.
In the study by Can Yaşar and Aral (2011), the researchers analyze 40 theses on drama in early childhood and underline the profusion of studies on the use of drama in early childhood education. Taştepe et al. (2016), who examined graduate theses on educational inclusion, identified the subject matters as "views about and attitude towards inclusion", "children with or without special needs in an inclusion setting", "efficacy of inclusive education programs", and "evaluation of teachers in an inclusion program and inclusion setting". In their study on theses, Kaytez and Durualp (2014) found that theses handled such subjects as linguistic, cognitive, socio-emotional development, self-care skills, concept development, mathematics education, communication, social and perspective-taking skills, games in special education and that the views of teachers, administrators, and parents were examined in game-focused practices and some of the theses were concerned with scale adaptation. Ahi and KIldan (2013) identified in the study on graduate theses that among the most researched subjects were education (science and nature teaching, mathematics education, creativity education, family-focused education, foreign language education, character education), development (cognitive development, linguistic development, socio-emotional development, motor development and physical development) and health (children with asthma, dietary habits and cleaning habits). It was observed in the research by Bertan et al. (2009) that one third of the analyzed theses on early childhood were education-focused. The other studies were conducted in health-related disciplines. Altun, Şendil and Şahin (2011) explored that no research was available on such subject matters as cultural diversity, measurement, assessment, and paternal contribution to education, internet, and children's rights.

In consideration of the fourth question "What is the distribution of the graduate theses in the corpus by research models/methods, data collection methods/tools, and population/sampling?", it was discovered that $68.1 \%$ of the 182 graduate theses herein were quantitative studies and screening method was used in $54 \%$ of them as expressed by the authors, while the least frequently used methods were found to be interview (1.6\%), phenomenology (1.6\%), case study $(1.1 \%)$, and observation $(0.5 \%)$.It was also revealed that $122(67 \%)$ of the studies in question used one data collection tool and the most frequently used (65\%) was questionnaire. Furthermore, it was observed that 118 of the graduate theses were conducted on a single sample group, while two were exploited by 54 studies and more than two by 10 .

It was observed in the study where Kaytez and Durualp (2014) analyzed 38 graduate theses that $32 \%$ of the theses employed screening model, while $45 \%, 16 \%$, and $5 \%$ made use of an experimental method, observation, and interview, respectively, and $2 \%$ were case studies. Durukan, Atalay and Şen (2015) figured out that the most frequently used research methods were quantitative methods, accounting for $78 \%$ of the corpus. It was revealed by Taştepe et al. (2016) that $76 \%, 16 \%$ and $8 \%$ of their corpus were quantitative, qualitative and both quantitative and qualitative studies, respectively. Can Yaşar and Aral (2011) identified $65 \%, 22.5 \%$, and $12.5 \%$ of the theses in their research as experimental, screening, and review studies, respectively. Ahi and Kıldan (2013) realized in their corpus that quantitative methods were used in majority of the theses, which was almost twice as high as the studies with qualitative and mixed methods combined. It was expressed that questionnaire was the most frequently used data collection tool. In the examined theses, children were among the most frequently studied groups. Moreover, they were also conducted over teachers, parents, preser- 
vice teachers, and school administrators.

Graduate education, referred to as the "heart" of higher education, is the domain most dramatically affected by any educational negligence. Graduate education was offered by faculties/colleges for years, but this responsibility was assigned to institutes at universities in 1982 (Bozan, 2012, p. 181). It was only in the 1950s could universities get out of Istanbul (Turkey's biggest city) and Ankara (Turkey's capital city), and it took a long while for them to spread across the rest of Turkey. In fact, there were only 27 universities back in 1983, when universities were brought together under an umbrella institution, the Council of Higher Education (Bozan, 2012, p. 179). Thanks to the Bologna Process, which aims to create a shared higher education environment in Europe and Turkey entered in 2001, Turkey intensified its innovative efforts in higher education. With the implementation of this process, undergraduate and graduate mobility has increased in the European countries, social dimension of the Bologna Process is strengthened, life-long learning is promoted, active participation of higher education institutions and students is encouraged, flexible teaching methods are created in higher education, and quality in higher education is safeguarded (YÖK, 2013: as cited in Ertürk, Özen Altınkaynak, Veziroğlu \& Erkan, 2014, p. 899). As cited by Gök (2015, p. 57), the number of undergraduate students has substantially increased in Turkey since the 1990s and has been doubled over the last ten years; accordingly, the number of universities have amounted to 193 (including some Private Vocational Schools owned by Foundations) (YÖK, 2015) and that of students to more than 6 million (including the ones from the Open University and distance education) (ÖSYM, 2015). However, the rate of graduate students, which accounts for $11.6 \%$ of the total population in higher education (YÖK, 2015), is still far lower than those in the developed countries. While the average number of researchers per a million people amounts to 5933 (2407 - 11000) in such developed countries as Finland, South Korea, Germany, Spain, France and Italy - which achieved the planned researcher figures years ago- (TÜBITAK, 2010), it is 1688 in Turkey (Çetinsaya, 2014).

Additionally, the number of researchers per ten thousands of people in these countries, which is considered as a standard of development, is 87 (38-162) in average and 70 in the OECD countries, whereas it amounts to 33 in Turkey (TÜBITAK, 2010). From this perspective, the number of graduate studies on early childhood education can be expected to grow higher as the number of researchers in faculties and institutions of education in particular increases.

The authors of the graduate theses should be encouraged to render their works easily accessible and the time of restriction should be shortened to the minimal period of time possible for a clearer manifestation of the results concerning the distribution of the examined theses by year and for an increased number of analyses of graduate theses. Given the fact that the graduate theses were conducted following a quantitative methodology and they produced generalizable results, it can be considered that the adoption of qualitative methods and experimental design to obtain more in-depth data can contribute to the field. It was observed that the graduate studies analyzed in the present study were mainly conducted in big cities. In consideration of the effects of inaccessibility to formal education and poverty on children's early development, the proliferation of studies on early childhood development across Turkey is crucial to help families raise awareness of this issue and for the proper development of future generations.

\section{References}

AÇEV-ERG, (2013). Erken çocukluk eğitimi ve "4+4+4" düzenlemesi, anne çocuk eğitim vakfı ve eğitim reformu girişimi. https://erg.sabanciuniv.edu/sites/ erg.sabanciuniv.edu/files/ACEV.ERG_ECE_PolitikaRaporu.

Ahi, B., \& Kıldan, A. O. (2013). Türkiye'de okul öncesi eğitimi alanında yapılan lisansüstü tezlerin incelenmesi. Mehmet Akif Ersoy Üniversitesi Eğitim Fakültesi Dergisi, 13(27), 23-46.

Altun, D., Şendil, Ç. Ö., \& Şahin İ. T. (2011). Investigating the national dissertation and thesis database in the field of early childhood education in Turkey. Procedia Social and Behavioral Sciences, 12, 483-492.

Arı, E., Kızılaslan Tunçer, B., \& Demir, M. K. (2016). Primary school teachers' views on constructive classroom management. International Electronic Journal of Elementary Education, 8(3), 363-378.

Bertan, M., Haznedaroğlu, D., Koln, P., Yurdakök, K., \& Güçiz, B. D. (2009). Ülkemizde erken çocukluk gelişimine ilişkin yapılan çalışmaların derlenmesi (2000-2007). Çocuk Sağ/ığı ve Hastalıkları Dergisi, 52, $1-8$.

Birol, Y. (2013). Bilimsel araştırmanın temelleri. S. Baştürk (Eds.), Bilimsel Araştırma Yöntemleri (pp. 1-31). Ankara: Vize Yayıncllık.

Bozan, M. (2012). Lisansüstü eğitimde nitelik arayışları. Sosyal ve Beşeri Bilimler Dergisi, 4(2), 177-187.

Can Yaşar, M., \& Aral, N. (2011). Türkiye'de okul öncesinde drama alanında yapılan lisansüstü tezlerin incelenmesi. Mehmet Akif Ersoy Üniversitesi Ĕgitim Fakültesi Dergisi, 11(22), 70-90.

Cohen, L., Manion, L., \& Morrison, K. (2007). Research Methods in Education. New York: Routledge.

Creswell, J. W. (2006). Understanding Mixed Methods Research, 01-Creswell (Designing)-45025.qxd 5/16/2006; http://www.sagepub.com/upm-data/10981_Chapter_1.pdf

Çetinsaya, G. (2014). Büyüme, Kalite, Ulus/ararasılaşma: Türkiye Yükseköğretimi içcin Bir Yol Haritası. https:// yolharitasi.yok.gov.tr/docs/YolHaritasi.pdf.

Durukan, H., Atalay, Y., \& Şen, S. N. (2015). Türkiye'de 20002014 yılları arasında okul öncesi eğitimi Alanında yapılan yüksek lisans tezlerinin Incelenmesi. Dicle Üniversitesi Ziya Gökalp Eğitim Fakültesi Dergisi, 26, 62-77.

Eğitim-Bir-Sen. (2010). Gelecek için eğitim raporu. EğitimBir-Sen Yayınları: 41. Ankara: Gözde Matbaacılık.

Erdoğan, M. (2007). Yeni geliştirilen dördüncü ve beşinci sınıf fen ve teknoloji dersi öğretim programının analizi; nitel bir çalışma. Türk Ĕgitim Bilimleri Dergisi, 5(2), 221-254.

Ertürk, H.G., Özen Altınkaynak, Ş., Veziroğlu, M., \& Erkan, S. (2014). Okul öncesi öğretmenlerin üniversite deneyimlerinin mesleki yaşantılarına etkisine ilişkin görüşlerinin belirlenmesi. Kastamonu Eğitim Dergisi, 22(3), 897-908. 
Gök, M. (2015). Türkiye'de lisansüstü eğitim, araştırmacı sayısı, araştırma görevlileri sorunları ve çözüm önerileri. Journal of Higher Education, 5(2), 57-64.

Günindi, Y. (2015). Preschool children's perceptions of the value of affection as seen in their drawings. International Electronic Journal of Elementary Education, 7(3), 371-382.

Johnson, R. B., \& Onwuegbuzie, A. J. (2004). Mixed methodsresearch: A research paradigm whose time has come. Educational Researcher, 33(7), 14-26.

Karadağ, E. (2009). Eğitim bilimleri alanında yapılmış doktora tezlerinin tematik açıdan incelenmesi. Ahi Evran Üniversitesi Eğitim Fakültesi Dergisi, 10(3), 7587.

Kaytaz, M. (2005). A Cost Benefit Analysis of Preschool Education in Turkey. İstanbul: Mother Child Education Foundation.

Kaytez, N., \& Durualp, E. (2014). Türkiye'de okul öncesinde oyun ile ilgili yapılan lisansüstü tezlerin incelenmesi. Uluslararası Türk Eğitim Bilimleri Dergisi, 2(2), 110-122.

Köse E. (2013). Bilimsel araştırma modelleri. R.Y. Kıncal (Eds.), Bilimsel Araştırma Yöntemleri (pp. 99-122). Ankara: Nobel Yayıncılık.

Oral, I., Yaşar, D., \& Tüzün, I. (2016). Her çocuğa eşit firsat: Türkiye'de Erken Çocukluk Eğitiminin Durumu ve Öneriler, Anne Çocuk Eğitim Vakfı (AÇEV) ve Eğitim Reformu Girişimi (ERG), http://erg.sabanciuniv. edu//sites/erg.sabanciuniv.edu/files/ACEV-ERG. Rapor.01.02.16.bsk.pdf

ÖSYM (2015). 2014-2015 Öğretim YIlı Yükseköğretim Istatistikleri. Ankara: ÖSYM.

Özdemir, S., Bacanlı, H., \& Sözer, M. (2007). Türkiye'de Okul Öncesi Eğitim Ve Ilköğretim Sistemi: Temel Sorunlar ve Çözüm Önerileri. Ankara: Türk Eğitim Derneği Yayını.

Taştepe, T., Öztürk Serter, G., Yurdakul, Y., Taygur Altuntaş, T., \& Bütün Ayhan, A. (2016). Türkiye'de okul öncesi dönemde kaynaştırma konusunda yapılan lisansüstü tezlerin incelenmesi. The Journal of Academic Social Science Studies, 49, 501-514.

TEDMEM (2017). Güçlü Bir Başlangıç 2017: Erken Çocukluk Eğitimi ve Bakımı. https://tedmem.org/mem-notlari/degerlendirme/guclu-bir-baslangic-2017-erkencocukluk-egitimi-ve-bakimi.

TÜBiTAK (2010). 2011-2016 Bilim ve Teknoloji Insan Kaynağı Stratejisi ve Eylem Planı. Ankara: Türkiye Bilimsel ve Teknik Araştırma Kurumu.

Yıldırım, A., \& Şimşek, H. (2005). Sosyal Bilimlerde Nitel Araştırma Yöntemleri. Ankara:Seçkin Yayıncılık.

YÖK (2015). Kararlar-Duyuru. 29 Mayıs, Ankara: YÖK.

https://istatistik.yok.gov.tr/yuksekogretimlstatistikleri/2016/2016_T28_v2.pdf 